\title{
POTENSI PANGSA PASAR PERGURUAN TINGGI SWASTA DI INDONESIA \\ [Studi Pada Universitas Islam Syekh-Yusuf Tangerang]
}

\author{
Femi Handayani \\ Universitas Islam Syekh-Yusuf Tangerang, Indonesia \\ Email: fhandayani@unis.ac.id
}

\begin{abstract}
Tujuan dari penelitian ini berkaitan dengan melakukan analisis potensi pangsa pasar perguruan tinggi swasta di Indonesia, studi pada Universitas Islam SyekhYusuf Tangerang. Dengan melakukan wawancara mendalam, observasi dan data yang berkaitan dengan potensi pangsa pasar. Hasil penelitian menunjukkan pangsa pasar pada Universitas Islam Syekh-Yusuf Tangerang adalah cukup potensial berkaitan dengan calon mahasiswa baru yang masuk. Penelitian ini memberikan saran bahwa pangsa pasar di perguruan tinggi swasta khususnya di Universitas Islam Syekh-Yusuf Tangerang perlu dijaga sehingga animo mahasiswa baru tetap tinggi.
\end{abstract}

Keywords: Pangsa pasar, potensi pangsa pasar, mahasiswa baru, perguruan tinggi swasta, universitas Islam Syekh-Yusuf Tangerang. 


\section{A. PENDAHULUAN}

Pangsa pasar adalah bagian atau luas pasar yang dikuasai oleh perguruan tinggi swasta (PTS) di dalam menjaring mahasiswa baru. Pangsa pasar ini tentu berkaitan dengan strategi pemasaran. Dengan produk yang dimiliki, maka tujuan memperluas pangsa pasar bisa dibantu dengan pemanfaatan promosi. Universitas Islam Syekh-Yusuf (UNIS) Tangerang berusaha untuk memuaskan pelanggan, membangun kepercayaan dan loyalitas konsumen, serta menciptakan keunggulan kompetitif yang berkelanjutan.

Untuk bisa bersaing, UNIS Tangerang senantiasa harus mampu menekan biaya produksi sehingga harga produk atau biaya kuliah tidak terus meningkat, hal ini penting dilakukan dengan didukung penggunaan teknologi informasi yang sesuai dengan kebutuhan. Begitupun dilihat dari tempat promosi harus lebih diperluas agar pangsa pasar yang dibidik semakin besar sehingga semakin banyak konsumen yang tertarik. Pemikirin ini dipertegas oleh Rahardika (2018:9) menjelaskan: "Rencana pemasaran strategis dapat ditinjau dari segi harga sebaiknya biaya produksi harus semakin ditekan didukung penggunaan teknologi agar ke depannya semakin banyak pasar konsumen yang bisa diraih. Dari segi tempat promosi harus lebih diperluas agar pangsa pasar yang dapat dibidik pun semakin besar agar semakin banyak konsumen yang mengenal dan berpotensi menjadi konsumen. Dari segi pengembangan produk didukung laboratorium penelitian yang memadai akan mengahsilkan produk yang lebih kompetitif di masa mendatang".

Mengenai pangsa pasar, dijelaskan oleh Lapan (2017:1) mengenai: "Pangsa pasar adalah salah satu indikator utama perusahaan yang digunakan untuk mengukur seberapa baik mereka lakukan dibandingkan pesaing. Pangsa pasar adalah persentase bisnis atau penjualan sebuah perusahaan yang memegang dari bisnis keseluruhan atau penjualan oleh semua pesaing gabungan di pasar tertentu. Total bisnis yang tersedia disebut potensi pasar. Ada dua cara dasar yang menyatakan angka pangsa pasar, meskipun perhitungan yang sebenarnya mungkin sulit untuk di dapatkan. Ada keuntungan dan kerugian untuk memiliki pasar yang besar pangsa relatif terhadap pesaing".

Mengkaji pangsa pasar pada intinya merupakan indikator utama untuk mengukur seberapa baik yang dilakukan UNIS Tangerang dibanding dengan pesaing. Pangsa pasar yang ada harus bisa dikuasai termasuk bisa mengukur kekuatan pesaing yang dinyatakan dalam persentasi, misal tahun 2018 berapa persen harus mendapatkan mahasiswa baru bila dibanding dengan tahun 2017, tentu mengacu pada peningkatan 
jumlah mahasiswa mendaftar, mengikuti tes, diterima dan registrasi ulang. Dengan demikian pangsa pasar UNIS Tangerang adalah berkaitan dengan faktor-faktor yang pertimbangan calon mahasiswa baru dalam memilih PTS sebagai tempat kuliah. Faktor-faktor tersebut tentu harus memiliki daya tarik bagi calon mahasiswa sehingga pilihannya adalah pilihan yang terbaik. Untuk itu UNIS Tangerang harus mengedepankan daya tarik tersendiri yang dibarengi dengan keunggulan-keunggulan yang dimiliki. Disamping itu perlu membangun citra yang dibentuk PTS memiliki peranan yang dominan dalam mempengaruhi sikap masyarakat, seperti PTS bisa memiliki citra sebagai perguruan tinggi yang murah, memiliki sistem penilaian yang baik, jadwal kuliah yang fleksibel, lokasi yang mudah dijangkau, atau memiliki sarana dan prasarana yang lengkap. Citra tersebut akan mempengaruhi calon mahasiswa dalam memilih PTS yang akan dipilih untuk pendidikan selanjutnya.

Faktor-faktor pertimbangan calon mahasiswa, mengedepankan daya tarik dan membangun citra sebuah universitas ini adalah bagian di dalam menetapkan ukuran keseluruhan pasar, dan pasar yang berencana untuk beroperasi dari pasar secara keseluruhan, setidaknya untuk memulai menyusun perencanaan strategis, perlu mencari tahu siapa pesaing yang dihadapi dan berapa banyak pasar yang mereka pegang (kuasai).

Lapan, (2017:1) menjelaskan: "Ketika melakukan perencanaan strategis, mengembangkan strategi bauran pemasaran, membangun rencana pemasaran dan mempersempit fokus pada segmentasi produk, maka perlu menjalankan melalui beberapa strategi yang kompetitif dan skenario untuk siap menghadapi perubahan tekanan kompetitif".

Bagi UNIS Tangerang, kualitas lulusan merupakan strategi yang dapat dijual guna meningkatkan pangsa pasar. Hal tersebut seperti dijelaskan oleh Hanafiah (2015:7) menyatakan: "Banyak organisasi menggunakan berbagai strategi untuk meningkatkan pangsa pasar, salah satunya melalui strategi kualitas. Dalam strategi pemasaran, konsumen merupakan tujuan jangka panjang perusahaan. Tujuan pemasaran adalah untuk memenuhi dan memuaskan kebutuhan serta keinginan konsumen". Strategi dan/atau taktik pemasaran merupakan hal yang utama untuk memenangkan pangsa pasar. Untuk memenangkan persaingan, UNIS Tangerang harus bisa menentukan pangsa pasar yang jelas sehingga dapat menganalisa peluang pasar dan pesaing sehingga dapat menerapkan promosi yang berbeda dengan pesaing. Inilah merupakan keunggulan yang harus dimiliki UNIS Tangeraang sehingga mampu melakukan persaingan dengan kompetitor. 
Pohan, (2011:39) menjelaskan: "Perusahaan dikatakan menjadi market leader (pemimpin pasar) apabila menguasai sebagian besar market share (pangsa pasar) dalam industrinya. Menurut Kotler (1994:312) dikutip Pohan (2010:40), menjelaskan: "Market leader adalah perusahaan yang memiliki market share terbesar dalam suatu pasar produk dan menjadi pemimpin dalam perubahan-perubahan dalam harga, produk baru, distribusi dan intensitas promosi".

Penguasaan pangsa pasar bagi calon mahasiswa yang masuk ke UNIS Tangerang ditahun 2017 yang lalu berapa persen dari jumlah lulusan SLTA yang ada di Tangerang? Hal ini penting mengingat UNIS Tangerang perlu memiliki market leader yang kuat. Para pesaing yang melihat besarnya pangsa pasar UNIS Tangerang tidak mau ketinggalan, seperti PTS yang ada di Tangerang terus melakukan tindakan yang agresif dalam merebut pangsa pasar. Menentukan potensi pangsa pasar yang tinggi bagi UNIS Tangerang harus dilakukan secara sungguh-sungguh dengan mengedepankan kekuatan dan peluang yang ada, termasuk keunggulankeunggulan yang dimiliki.

Hasyim, (2007:54) menjelaskan: "Dewasa ini PTS telah masuk kedalam mekanisme pasar yang bersifat ferfect competition untuk memproleh tempat dihati calon mahasiswa". Hasil penelitian yang berkaitan dengan faktor-faktor yang dipertimbangkan dalam memilih perguruan tinggi swasta, dilakukan oleh Hasyim (2007:55-56) meliputi: (1) biaya kuliah; (2) reputasi perguruan tinggi; (3) lokasi perguruan tinggi; (4) ikut teman atau dorongan orang tua; (5) kualitas dosen; (6) kualitas lulusan; (7) pilihan program /fakultas; (8) fasilitas: ketersediaan fasilitas perkuliahan; dan (9) akreditasi.

Dari kajian tersebut menunjukkan bahwa faktor-faktor yang menjadi pertimbangan mahasiswa untuk memilih PTS yang diinginkan tentu berkaitan dengan pangsa pasar yang merupakan bagian yang harus dikuasai oleh UNIS Tangerang dan seluruh potensi jual yang dapat dinyatakan dalam persentase. Untuk menarik mahasiswa baru juga perlu membangun citra dan penentuan harga sehingga lembaga dapat mengukur prime competitor (pesaing yang kuat), kualitas produk dan layanan, serta pangsa pasar dan kekuatan pesaing. Dengan demikian pangsa pasar adalah persentase total dari penjualan suatu produk dengan total penjualan jasa ataupun produk dalam industri PTS. Pangsa pasar merupakan bagian dari pasar yang dapat dicapai UNIS Tangerang sebagai PTS. Untuk menjamin pangsa pasar bisa dikuasai, perlu melakukan riset pasar guna mencari tahu apa pangsa pasar yang cocok dan untuk menentukan ukuran pasar yang diinginkan. Namun demikian, apapun usaha yang dilakukan hanya 
sebagai bentuk ikhtiar, namun diyakini setiap orang sudah Allah azza wajjala tentukan, karenanya agar usaha membuahkan hasil selain ihktiar juga harus berdo'a sehingga mendapat keberkahan.

Dengan demikian, penelitian potensi pangsa pasar di PTS dinilai sangat unik, karenanya menarik untuk dilakukan penelitain lebih mendalam, dengan judul: Potensi Pangsa Pasar Perguruan Tinggi Swasta (PTS) di Indonesia, Studi pada Universitas Islam Syekh-Yusuf Tangerang.

\section{B. KAJIAN TEORITIKAL \\ A. Definisi Pangsa Pasar}

Penguasaan pasar dalam satu industri tentu memerlukan strategi bisnis dalam pencapaiannya. Menurut Tjiptono (1997) dikutip Pohan (2010:41), menjelaskan: "Perusahaan yang menjadi market leader biasanya melakukan tiga strategi untuk dapat terus mempertahankan posisinya, yaitu:

a. Mengembangkan pangsa pasar. Ini dapat dilakukan dengan melakukan pengembangan lini produk dan pengenalan produk baru untuk member nilai lebih bagi konsumen dibanding pesaing. Pengembangan ini juga harus disertai oleh tindakan pada variabel pemasaran seperti harga dan jaringan distribusi untuk mengantisipasi apa yang pesaing lakukan kedepan dan juga sebagai reaksi dari apa yang dilakukan pesaingsebelumnya.

b. Mempertahankan pasar dengan menciptakan entry barrier yang sulit atau bahkan tidak mungkin dilakukan pesaing (Hasan, 2008). Ini dapat dilakukan dengan:

- Pertahanan posisi (position defense), yaitu membangun benteng yang kokoh dan sulit direbut didaerah kekuasaan, tapi tidak hanya dengan menjaga dan mempertahankan posisi produk saat ini saja, tapi jugamengembangkan produk ataupun strategi diversifikasi usaha.

- Pertahanan aktif mendahului (preempetive defense), menyerangsebelum diserang, baik pada produk berkualitas, distribusi yang intensif, serta layanan yang bersahabat.

- Pertahanan serangan balik (counter offensive defense), mengidentifikasidan memanfaatkan celah - celah atau kelemahan dari tindakan lawan".

c. Menjaga hubungan baik dengan pelanggan, tujuannya untuk membuat pelanggan lebih tertarik untuk tetap setia dan lebih sulit untuk berpindah. Bentuknya bermacam-macam bisa dilakukan dengan program membership ataupun pemberian point reward. 
Ketiga strategi yang digunakan pada market leader ini sangat mendukung market share (pangsa pasar) karena dengan penguasaan pasar maka pangsa pasar dapat dikuasai dengan baik; termasuk diperlukannya riset pasar. Namun demikian, agar market leader dan market share terus tumbuh tentu perlu mempertimbangkan secara seksama siapa yang menjadi kompetitor. Dengan mengetahui kekuatan kompetitor maka kemampuan yang dimiliki dapat menjadi ukuran, UNIS berada pada posisi di bawah atau pada posisi di atas kompetitor sehingga UNIS bisa bersaing atau sebaliknya kalah bersaing. Oleh karena itu strategi market leader (penguasaan pasar) harus bisa dibangun dengan baik.

Kamus Bisnis \& Bank, dalam http://www.mediabpr.com/kamusbisnis-bank/pangsa_pasar.aspx), menjelaskan: “Pangsa pasar adalah market segment yaitu: bagian dari keseluruhan permintaan suatu barang yang mencerminkan golongan konsumen menurut ciri khasnya, seperti tingkat pendapatan, umur, jenis kelamin, pendidikan, dan status sosial". Pangsa pasar merupakan bagian dari pasar yang dapat dicapai oleh perusahaan. Pangsa pasar dapat menjadi salah satu dari indikator meningkatnya kinerja pemasaran suatu perusahaan.

Namun demikian, pangsa pasar tidak selalu menjadi indikator keberhasilan kinerja perusahaan mengingat ada perusahaan yang sama yang bermain pada pangsa pasar yang sama; artinya ada banyak kompetitor yang selalu berhadapan. Oleh karena itu diperlukan strategi market leader sehingga perusahaan berada pada pemimpin pasar.

Pangsa pasar dewasa ini semakin penting mengingat pangsa pasar ini menjadi indikator guna mengukur seberapa baik dengan membandingkan pesaing yang ada. Pengukuran ini biasanya dengan persentasi pencapaian mahasiswa baru, bisa dengan angka-angka atau secara kualitatif deskriptif berkaitan dengan wawancara dan/atau pengamatan yang dilakukan melalui riset pasar. Untuk itu, dipertegas oleh Lapan (2017:1) menyatakan: "Pangsa pasar adalah salah satu indikator utama perusahaan gunakan untuk mengukur seberapa baik mereka lakukan dibandingkan pesaing. Pangsa pasar adalah persentase bisnis atau penjualan sebuah perusahaan pegang dari bisnis keseluruhan atau penjualan oleh semua pesaing gabungan di pasar tertentu. Total bisnis yang tersedia disebut potensi pasar".

Pangsa pasar ini menjadi sangat penting mengingat sebagai indikator kekuatan dalam menghadapi pesaing sehingga total bisnis yang berupa perosentase dapat direncanakan melalui strategi bersaing, Asmawi, (2018:16) menjelaskan: “Dengan melakukan analisa kekuatan dan peluang 
digabung untuk memperoleh manfaat yang maksimal serta kelemahan dan ancaman digabung untuk meredam atau meminimalisasi dampak negatif".

\section{B. Faktor-Faktor Pertimbangan Memilih PTS}

Dari pendekatan perilaku konsumen bahwa calon mahasiswa merupakan konsumen dari suatu perguruan tinggi, hal ini berarti konsumen adalah masyarakat yang memiliki penilaian, kebutuhan, pendapat, sikap, dan selera yang berbeda-beda sehingga pengambilan keputusan dipengaruhi oleh beberapa faktor. Kotler (2008:25) dikutip oleh Handayani (2017:13) menjelaskan: "Faktor yang mempengaruhi perilaku konsumen terdiri dari: (1) faktor kebudayaan. Faktor kebudayaan berpengaruh luas dan mendalam terhadap perilaku konsumen. Faktor kebudayaan terdiri dari: budaya, sub-budaya, kelas sosial; (2) faktor sosial. Selain faktor budaya, perilaku seorang konsumen dipengaruhi oleh faktorfaktor sosial seperti kelompok acuan, keluarga serta status sosial; dan (3) faktor pribadi. Faktor pribadi yang memberikan kontribusi terhadap perilaku konsumen terdiri dari: usia dan tahap siklus hidup, pekerjaan dan lingkungan ekonomi, gaya hidup, kepribadian dan konsep diri; dan (4) faktor psikologis. Pilihan pembelian seseorang dipengaruhi oleh empat factor psikologi utama yaitu motivasi, persepsi, pembelajaran, serta keyakinan dan pendirian".

Dalam penelitian ini bertujuan untuk mengetahui pengaruh dari publik relations dan pencitraan terhadap minat informasi kepada calon mahasiswa, sehingga calon mahasiswa tersebut tertarik dan memilih PTS tersebut sebagai tempat untuk melanjutkan studi. Walaupun public relations sering dihubungkan dengan pencitraan, tetapi kenyataannya public relations mempunyai arti yang luas. Susanti, (2017:3) menjelaskan: "Pelaksanaan perencanaan mencapai tujuan citra posisif perusahaan, diperlukan adanya teknik komunikasi yang tepat agar efektif dalam menyampaikan pesan kepada publik. Komunikasi yang pada prinsipnya adalah penyampaian pesan untuk dapat menimbulkan dampak atau efek tertentu pada publik sasaran (komunikan) sehingga penggunaan teknik komunikasi harus memperhatikan publik sasaran agar dapat merekayasa jiwa publiknya (komunikan) sehubungan dengan perubahan sikap, pandangan dan perilaku tertentu sesuai dengan keinginan perusahaan".

Untuk memilih PTS yang sesuai tentu berkaitan dengan berbagai faktor. Faktor-faktor yang menjadi pertimbangan dalam memilih perguruan tinggi swasta, dilakukan oleh Hasyim (2007:55-56) meliputi: (1) biaya kuliah; (2) reputasi perguruan tinggi; (3) lokasi perguruan tinggi; (4) ikut teman atau dorongan orang tua; (5) kualitas dosen; (6) kualitas lulusan; 
(7) pilihan program /fakultas; (8) fasilitas: ketersediaan fasilitas perkuliahan; dan (9) akreditasi.

Selain pertimbangan tersebut, Wijaya (2000:28) menjelaskan: "Identifikasi faktor-faktor utama yang mempngaruhi mahasiswa dan berkuliah, meliputi: (1) sarana prasarana pendidikan; (2) jasa pelayanan yang disediakan; (3) kemudahan pembayaran biaya kuliah; (4) kualitas sumber daya mnusis; (5) lokasi kampus; (6) sarana prasaran kegiatan pendukung; (7) kegiatan promosi; (8) citra kampus; dan (9) fasilitas penukung".

\section{Mengembangkan Pangsa Pasar}

Mengembangkan dunia pangsa pasar pada PTS bisa dilakukan dengan memperluas saluran distribusi, hal ini dilakukan untuk memperkenalkan dan mendekatkan UNIS Tangerang kepada konsumen, berdasarkan analisis konsumen tingkat pelayanan pada jaringan distribusi dan kemudahan mendapatkan akses akan menjadi faktor yang ikut menentukan keputusan konsumen untuk melakukan pembelian yakni memilih UNIS Tangerang sebagai tempat kuliah.

Pangsa pasar mendeskripsikan kekuatan dari setiap organisasi dalam pasar. Semakin tinggi nilai pangsa pasar yang dimiliki oleh organisasi maka kekuatan pasarnya akan semakin besar. Hal ini mengindikasikan bahwa PTS tertentu mampu bersaing dalam persaingan yang terjadi. Apabila nilai pangsa pasar kecil maka dapat dikatakan bahwa PTS tersebut tidak mampu bersaing dengan PTS lainnya karena tidak memiliki kekuatan untuk mengendalikan pasar yang ada.

Naylah, 2010, dikutip Hendra \& Hartomo, 2017:39) menjelaskan: "Setiap perusahaan memiliki pangsa pasarnya sendiri, dan besarnya berkisar antara 0 hingga 100 persen dari total keluaran seluruh pasar. Menurut literature Neo-Klasik, landasan posisi tawar perusahaan adalah pangsa pasar yang diraihnya. Pangsa pasar dalam praktik bisnis merupakan tujuan/motivasi perusahaan. Perusahaan dengan pangsa pasar yang lebih baik akan menikmati keuntungan dari penjualan produk dan kenaikan harga sahamnya".

Hendra \& Hartomo, 2017:39-40) menjelaskan: "Peranan pangsa pasar seperti halnya elemen struktur pasar yang lain adalah sebagai sumber keuntungan bagi perusahaan. Dengan demikian dapat diketahui bahwa pangsa pasar telah menjadi indikasi yang kuat dalam menilai kekuatan pasar. Sudah jelas bahwa apabila pangsa besar tinggi maka bank tersebut sangat berpengaruh terhadap pasar, begitu juga dengan sebaliknya apabila 
nilai pangsa pasar rendah maka kekuatan mempengaruhi pasar sangatlah rendah".

Lebih lanjut mengenai bagimana melihat volume penjualan, Pratama (2015:1) menjelaskan:

"Pangsa pasar relatif merupakan suatu perbandingan volume penjualan yang dikuasai perusahaan tertentu dibandingkan dengan volume penjualan yang dikuasai oleh pesaing utama perusahaannya. Pangsa pasar ini biasanya berwujud sebuah angka mutlak dan bukan dalam bentuk persentase. Jika besarnya pangsa pasar ini lebih besar dibandingkan satu itu artinya volume penjualan suatu perusahaan jauh lebih besar dibandingkan dengan volume penjualan pesaing pokoknya. Sebaliknya jika pangsa pasar yang dikuasai perusahaan tertentu lebih rendah dibandingkan satu, maka perusahaan tersebut diartikan sebagai perusahaan yang lemah dibanding pesaingnya. Tanpa memperdulikan berapa besar pangsa pasar yang dikuasai oleh perusahaan tersebut".

Mencermati kajian di atas, semakin memberikan pemahaman yang mendalam bahwa pangsa pasar itu memiliki makna yang strategis karena ketika bicara pangsa pasar itu tergambarkan volume penjualan perusahaan dibandingkan dengan pesaing. Pesaing ini menjadi sesuatu yang menjadi perhitungan ketika membangun pangsa pasar; artinya pesaing itu mempertimbangkan faktor-faktor yang menjadi pertimbangan mahasiswa memilih tempat kuliah.

Menurut Yavas dan Shemwell (19960); Hidayani dan Syafrizal (2008) dikutip Hariayanto (n.d:2), menjelaskan: "Posisi atau citra yang dibentuk oleh suatu perguruan tinggi memiliki peranan yang dominan dalam mempengaruhi sikap masyarakat terhadap perguruan tinggi tersebut. Sebagai contoh perguruan tinggi bisa memiliki citra sebagai perguruan tinggi yang murah, memiliki sistem penilaian yang baik, jadwal kuliah yang fleksibel, lokasi yang mudah dijangkau, atau memiliki sarana dan prasarana yang lengkap. Citra tersebut akan mempengaruhi calon mahasiswa dalam memilih universitas yang akan dipilih untuk pendidikan selanjutnya".

Mengenai PTS yang memiliki citra positif ini, dipertegas oleh Supandi, (2011:98) menjelaskan: "Prime competitor adalah pesaing yang memiliki posisi kuat di pasar. Perguruan tinggi level ini tidak saja memiliki finansial cukup mapan dibanding yang lain, tapi juga memiliki kualitas produk dan layanan yang baik. Mereka memiliki citra positif di masyarakat. Dalam persaingan pangsa pasar, merekalah yang disebut sebagai market leader". 
Keunggulan yang dibangun PTS ini harus dapat dibedakan dengan produk lain dan memiliki citra tersendiri, dengan demikian produk akan mampu bersaing. Mengenai citra produk ini juga berkaitan dengan penentuan harga (pricing), seperti dijelaskan oleh Hanafiah, (2015:39) menyatakan: "Strategi penentuan harga (pricing) sangat signifikan dalam pemberian nilai kepada konsumen dan mempengaruhi citra produk, serta keputusan untuk membeli".

Mengenai kajian tersebut sebenarnya bertumpu pada bagaimana membangun citra lembaga dimata masyarakat. Citra lembaga ini sangat mahal nilainya karena kalau citra lembaga ini sudah terbangun dibenak pikiran masyarakat maka lembaga tersebut menunjukkan posisi yang kuat di dalam melakukan persaingan dengan kompetitor. Oleh karena itu citra lembaga harus dijaga dan terus dibangun. Pimpinan lembaga memiliki peran penting dalam membangun citra yang baik ini dimata konsumen. Dalam hal ini diperlukan seorang pemimpin, seperti dijelaskan oleh Asmawi (2017:109) menyatakan:

"Applying a suitable leadership style for a university organization is a fundamental requirement that should be understood by a leader. Since university is very different compared to the principles of the organization in general, a suitable leadership style that aligns with its followers and the objective to be achieved by the organization is needed in order to lead a university".

Dari kajian tersebut menunjukkan bahwa untuk membangun citra lembaga itu memang diperlukan seorang pemimpin yang mampu membangun pengikutnya di dalam mencapai tujuan organisasi yang diinginkan, termasuk organisasi universitas dimana pemimpin memiliki peran yang sangat penting.

Dengan demikian, semakin jelas bahwa untuk mempengaruhi masyarakat agar bisa masuk ke PTS selain dengan citra produk yang ditawarkan juga harga jual (biaya kuliah) sehingga memiliki keputusan untuk membeli, sehingga pangsa pasar dituju memiliki potensi atau tidak. Mengenai kajian penelitian mengenai potensi pangsa pasar perguruan tinggi swasta di Indonesia ini meliputi aspek-aspek, yakni: (1) membangun citra dan penentuan harga; (2) prime competitor, kualitas produk dan layanan: (3) pangsa pasar dan kekuatan pesaiang; dan (4) faktor-faktor yang dipertimbangkan untuk memilih perguruan tinggi.

\section{METODOLOGI PENELITIAN \\ 1. Tipe Penelitian}

Mengenai pendekatan yang digunakan dalam penelitian ini adalah kualitatif. Alasan penggunaan pendekatan kualitatif adalah karena 
penelitian ini ingin menganalisis dan menggambarkan potensi pasar pada perguruan tinggi di Indonesia, khusunya pada Universitas Islam SyekhYusuf Tangerang. Seberapa besar pangsa pasar yang bisa dikuasai dibanding dengan pesaing, sehingga nantii dapat diketahui jumlah mahasiswa yang mendaftar; termasuk mahasiswa yang registrasi.

\section{Koleksi Data}

Proses pengumpulan data ini melalui beberapa teknik, meliputi:

\subsection{Wawancara Mendalam}

Mengenai wawancara ini dilakukan secara terbuka, dengan menggunakan alat pencatatan, dan dengan mengajukan pertanyaanpertanyaan yang berkaitan dengan permasalahan, peristiwa, atau kasus yang sesuai fokus penelitian. Informasi yang telah terkumpul didiskusikan kembali dengan informan, hal ini dimaksudkan agar benar-benar mendapatkan data yang mendalam. Data yang dianggap masih belum cukup memadai atau meragukan, maka dapat dilakukan wawancara mendalam sesuai fokus penelitian, sehingga penggalian informasi dapat menghasilkan tingkat kecukupan.

\subsection{Observasi}

Menegnai teknik pengumpulan data melalui observasi atau pengamatan ini dipergunakan untuk mengamati berbagai aktivitas yang berkaitan dengan fokus penelitian. Pengamatan itu ada yang bersifat terencana; artinya peneliti sengaja menyusun rencana observasi pada titiktitik aktivitas yang penting berkaitan dengan aktivitas di perguruan tinggi swasta. Sedang pengamatan yang bersifat insidental atau secara tidak sengaja; di mana peneliti tidak mempersiapkan diri terlebih dahulu, namun melakukan pengamatan yang relevan dengan fokus penelitian.

\subsection{Dokumentasi}

Teknik pengumpulan data melalui dokumentasi ini dilakukan untuk mengumpulkan, menyusun dan memilah data-data sekunder yang berupa dokumen-dokumen yang diperlukan. Data yang terkumpul, selanjutnya dilakukan sortir; yakni dipisah-pisah menurut relevansinya; artinya sejauhmana data tersebut diperlukan untuk menjelaskan suatu topik. 


\subsection{Analisa Data}

Data analisis adalah secara kualitatif, di mana data yang sudah terkumpul direduksi berupa pokok-pokok temuan yang relevan dengan peristiwa atau kasus sesuai fokus penelitian, selanjutnya disajikan secara naratif. Dengan demikian data disajikan secara deskriptif, faktual dan sistematis. Proses selanjutnya adalah penarikan kesimpulan, analisa data ini merupakan uraian logis, di mana baik data yang bersifat kualitatif maupun kuantitatif (data sekunder) disajikan dengan saling melengkapi.

Miles; Huberman; \& Saldana, 2014) menjelaskan: "Menganalisa data adalah langkah-langkah sebagai berikut: (1) pengumpulan data; (2) kondensasi data; (3) penyajian data; dan (4) penarikan kesimpulan: drawing / verifikasi. Pertama, pengumpulan data. Data yang dikumpulkan bersumber dari: (1) informan, yakni seseorang yang memberikan informasi dalam suatu wawancara sesuai dengan fokus penelitian; (2) peristiwa, yakni objek atau peristiwa dalam membangun potensi pasar di perguruan tinggi swasta di Inonesia. Kedua, reduksi data. Reduksi data adalah proses pemilihan, pemusatan perhatian pada penyederhanaan, pengabstrakan dan tranformasi data kasar yang muncul dari catatan tertulis di lapangan. Ketiga, penyajian data. Data yang disajikan berupa: (1) ulasan deskripsi data hasil pengamatan; (2) tabel, bagan, atau angka-angka; (3) gambar atau foto. Keempat, penarikan kesimpulan. Kegiatan analisis terakhir adalah menarik kesimpulan".

Dengan demikian hasil akhir dari penelitian adalah membuat kesimpulan mengenai potensi pasar perguruan tinggi swasta di Indinesia yang berupa "pemberian makna" dan alasannya dari uraian bahasan peneliti, yang dapat diperkuat, berlawanan dalam ulasan penjelasan teoritis dan empirik baik secara kualitatif dan kuantitatif. Penelitian itu pada hakekatnya adalah menguji teori dengan kenyataan di lapangan; yakni teori mengenai potensi pasar yang bisa dibangun. 


\section{TEMUAN PENELITIAN}

\section{Potensi Pangsa Pasar Perguruan Tinggi Swasta di Indonesia}

\subsection{Membangun Citra dan Penentuan Harga}

\subsubsection{Citra dan Penentuan Harga}

UNIS telah mampu membangun citra yang baik dan itu dapat diketahui oleh masyarakat, termasuk harga, yakni biaya kuliah yang terjangkau. Walaupun yang lain ada yang mengkaitkan bahwa UNIS Tangerang masih belum banyak diketahui oleh masyarakat. Mengani hal ini sebenarnya hanya sebagian kecil yang masih belum tahu dengan UNIS Tangerang.

Susanti, (2017:3) menjelaskan: “Pelaksanaan perencanaan mencapai tujuan citra posisif perusahaan, diperlukan adanya teknik komunikasi yang tepat agar efektif dalam menyampaikan pesan kepada publik". Untuk memilih PTS yang sesuai tentu berkaitan dengan berbagai faktor. Faktorfaktor yang dipertimbangkan dalam memilih perguruan tinggi swasta, dilakukan oleh Hasyim (2007:55-56) meliputi: (1) biaya kuliah; (2) reputasi perguruan tinggi; (3) lokasi perguruan tinggi; (4) ikut teman atau dorongan orang tua; (5) kualitas dosen; (6) kualitas lulusan; (7) pilihan program /fakultas; (8) fasilitas: ketersediaan fasilitas perkuliahan; dan (9) akreditasi.

Hanafiah, (2015:39) menjelakan: "Strategi penentuan harga (pricing) sangat signifikan dalam pemberian nilai kepada konsumen dan mempengaruhi citra produk, serta keputusan untuk membeli". Oleh karena itu UNIS Tangerang senantiasa mampu membuat citra yang positif dengan memperhatikan nilai harga atau biaya kuliah yang terjangkau. Kalau biaya kuliah dapat dijangkau, artinya masyarakat tidak merasakan mahal maka sebenarnya harga atau biaya kuliah tersebut cukup baik.

\subsubsection{Membangun Citra dan Penentuan Harga di UNIS Tangerang}

Membangun citra bagi UNIS Tangerang ini perlu terus dilakukan karena citra ini berkaitan dengan reputasi yang dimilikinya, termasuk mempertimbangkan harga atau biaya kuliah yang terus bisa dijangkau oleh mahasiswa baru.

Menganai citra lembaga ini dijelaskan oleh Asmawi (2017:109) yang menyatakan: 
"Applying a suitable leadership style for a university organization is a fundamental requirement that should be understood by a leader. Since university is very different compared to the principles of the organization in general, a suitable leadership style that aligns with its followers and the objective to be achieved by the organization is needed in order to lead a university".

Untuk membangun citra lembaga itu memang diperlukan seorang pemimpin yang mampu membangun pengikutnya di dalam mencapai tujuan organisasi yang diinginkan, termasuk organisasi universitas dimana pemimpin memiliki peran yang sangat penting. Untuk mempengaruhi masyarakat agar bisa masuk ke PTS selain dengan citra produk yang ditawarkan juga harga jual (biaya kuliah) sehingga memiliki keputusan untuk membeli, sehingga pangsa pasar dituju memiliki potensi yang besar. Mahasiswa baru tetap tertarik untuk kuliah di UNIS tangerang mengingat biaya kuliahnya cukup murah.

Untuk menarik mahasiswa baru juga perlu membangun citra dan penentuan harga sehingga lembaga dapat mengukur prime competitor (pesaing yang kuat), kualitas produk dan layanan, serta pangsa pasar dan kekuatan pesaing.

\subsubsection{Citra Kuliah di UNIS Tangerang Lebih Baik}

Mengenai kuliah di UNIS Tangerang ini dapat peneliti tegaskan bahwa citra kuliah di UNIS Tangerang ini adalah lebih baik, hal ini diakui oleh banyak pendapat bahwa biaya kuliah di UNIS Tangerang terjangkau oleh mahasiswa. Banyak factor yang menjadi pertimbangan untuk kuliah di UNIS Tangerang, seperti dijelaskan oleh Wijaja, (2000:28) mengenai: "Meliputi: (1) sarana prasarana pendidikan; (2) jasa pelayanan yang disediakan; (3) kemudahan pembayaran biaya kuliah; (4) kualitas sumber daya mnusis; (5) lokasi kampus; (6) sarana prasaran kegiatan pendukung; (7) kegiatan promosi; (8) citra kampus; dan (9) fasilitas penukung".

Kalau mencermati pendapat di atas, sebenarnya bukan hanya citra kampus yang baik masih terdapat faktor lain, seperti sarana dan prasarana, pelayanan, biaya kuliah yang murah, kegiatan promoso dan fasilitas pendukung. Jadi sebenarnya banyak factor-faktor yang mempengaruhinya.

Citra kampus memang sangat utama, namun yang paling menentukan seseorang itu bisa masuk kuliah adalah factor biaya kuliah yang terjangkau. Citra kuliah ini menjadi begitu penting khususnya berkaitan dengan biaya kuliah. 


\subsubsection{Kalau di UNIS Harga Kuliah Lebih Baik, Maka Lebih Banyak Mahasiswa Yang Masuk}

Potensi pangsa pasar perguruan tinggi swasta di Indnesia; khusunya pada UNIS Tangerang cukup potensil. Hal ini di dasarkan pada jumlah mahasiswa baru yang sudah melakukan daftar ulang dari tahun 2016/2017 dan 2017/2018 cukup ada peningkatan; yakni 1.339 orang dan 1.461 orang (UPT Humas dan Markting, 2018).

Berdasar pada data tersebut menunjukkan bahwa kuliah di UNIS Tangerang adalah lebih baik dengan pertimbangan harga kuliah yang seimbang. Untuk bisa bersaing, UNIS Tangerang senantiasa harus mampu menekan biaya produksi sehingga harga produk atau biaya kuliah tidak terus meningkat, hal ini penting dilakukan dengan didukung penggunaan teknologi informasi yang sesuai dengan kebutuhan. Pemikirin ini dipertegas oleh Rahardika (2018:9) menjelaskan: "Rencana pemasaran strategis dapat ditinjau dari segi harga sebaiknya biaya produksi harus semakin ditekan didukung penggunaan teknologi agar ke depannya semakin banyak pasar konsumen yang bisa diraih".

Menurut Kotler (1994:312) dikutip Pohan (2010:40), menjelaskan: "Market leader adalah perusahaan yang memiliki market share terbesar dalam suatu pasar produk dan menjadi pemimpin dalam perubahan-perubahan dalam harga, produk baru, distribusi dan intensitas promosi".

Untuk menarik mahasiswa baru juga perlu membangun citra dan penentuan harga sehingga lembaga dapat mengukur prime competitor (pesaing yang kuat), kualitas produk dan layanan, serta pangsa pasar dan kekuatan pesaing. Untuk itu UNIS Tangerang adalah salah satu competitor bagi perguruan tinggi swasta yang ada di Tangerang.

(Naylah, 2010, dikutip Hendra \& Hartomo, 2017:39) menjelaskan: "Setiap perusahaan memiliki pangsa pasarnya sendiri, dan besarnya berkisar antara 0 hingga 100 persen dari total keluaran seluruh pasar. Menurut literature Neo-Klasik, landasan posisi tawar perusahaan adalah pangsa pasar yang diraihnya. Pangsa pasar dalam praktik bisnis merupakan tujuan/motivasi perusahaan. Perusahaan dengan pangsa pasar yang lebih baik akan menikmati keuntungan dari penjualan produk dan kenaikan harga sahamnya".

Dengan demikian kalau kuliah di UNIS Tangerang biaya kuliahnya lebih baik, maka diharapkan mahasiswa barunya cenderung ada peningkatan dari tahun ke tahun. Hal ini benar bahwa tahun 2017 dan 2018 memang ada peningkatan.

\subsection{Prime Competitor (Pesaing Utama) Kualitas Produk dan Layanan}




\subsubsection{UNIS Sekarang Menjadi Pesaing Utama}

UNIS Tangerang masih menjadi pesaing diantara perguruan tinggi yang ada di Tangerang bahkan ada yang berpendapat menjadi peasaing utama di Banten. Hal ini memang benar bahwa UNIS Tangerang menjadi perguruan tinggi swasta pertama di Banten. Oleh karena itu dewasa ini menjadi pesaing utama dari perguruan tinggi swasta yang ada.

Pratama (2015:1) menjelaskan: "Pangsa pasar relatif merupakan suatu perbandingan volume penjualan yang dikuasai perusahaan tertentu dibandingkan dengan volume penjualan yang dikuasai oleh pesaing utama perusahaannya. Pangsa pasar ini biasanya berwujud sebuah angka mutlak dan bukan dalam bentuk persentase".

Mencermati kajian di atas, semakin memberikan pemahaman yang mendalam bahwa pangsa pasar itu memiliki makna yang strategis karena ketika bicara pangsa pasar itu tergambarkan volume penjualan perusahaan dibandingkan dengan pesaing. Pesaing ini menjadi sesuatu yang menjadi perhitungan ketika membangun pangsa pasar; artinya pesaing itu mempertimbangkan faktor-faktor yang menjadi pertimbangan mahasiswa memilih tempat kuliah.

Faktor-faktor pertimbangan bagi mahasiswa untuk bisa memilih perguruan tinggi yang layak dipilihnya, salah satunya adalah aspek citra dan harga atau biaya kuliah yang bisa dijangkau sehingga ini menjadi pilihan.

\subsubsection{Pesaing Dalam Aspek Apa}

UNIS Tangerang tetap menjadi pesaing yang baik dalam hal yang berkaitan dengan pencapaian calon mahasiswa baru. Mahasiswa memilih UNIS Tangerang tentu dengan berbagai hal yang dipertimbangkan, termasuk menjadi pesaing dalam banyak aspek.

Pesaing ini menjadi sesuatu yang menjadi perhitungan ketika membangun pangsa pasar; artinya pesaing itu mempertimbangkan faktorfaktor yang menjadi pertimbangan mahasiswa memilih tempat kuliah.

Mengenai PTS yang memiliki citra positif ini, dipertegas oleh Supandi, (2011:98) menjelaskan: "Prime competitor adalah pesaing yang memiliki posisi kuat di pasar. Perguruan tinggi level ini tidak saja memiliki finansial cukup mapan dibanding yang lain, tapi juga memiliki kualitas produk dan layanan yang baik. Mereka memiliki citra positif di masyarakat. Dalam persaingan pangsa pasar, merekalah yang disebut sebagai market leader". 
Posisi market leader ini tidak hanya seketika mejadi perguruan tinggi tetapi perguruan tinggi yang sudah lama berjalan dengan tetap memperlihatkan kinerjanya yang baik. Pengalaman waktu memang sebagai suatu ujian namun memang UNIS Tangerang berada pada posisi pesaing yang kuat.

Mengenai pangsa pasar, dijelaskan oleh Lapan (2017:1) menyatakan: "Pangsa pasar adalah salah satu indikator utama perusahaan yang digunakan untuk mengukur seberapa baik mereka lakukan dibandingkan pesaing. Pangsa pasar adalah persentase bisnis atau penjualan sebuah perusahaan yang mempegang dari bisnis keseluruhan atau penjualan oleh semua pesaing gabungan di pasar tertentu".

\subsubsection{Kualitas Produk Yang Dihasilkan UNIS Lebih Baik}

Kualitas produk yang dihasilkan UNIS memperlihatkan situasi yang baik, hal ini memang benar yang dapat dilihat dari capaian mahasiswa bari di tahun 2017 dan 2018 dewasa ini. Kualitas produk yang dihasilkan UNIS Tangerang adalah lebih baik, hal ini ditarik dari banyak pendapat. Memang benar kualitas produk ini adalah kualitas lulusan yang dihasilkan UNIS Tangerang, yakni lulusan UNIS yang sudah bekerja menunjukkan kualitas kerja yang baik.

Supandi, (2011:98) menjelaskan: "Prime competitor adalah pesaing yang memiliki posisi kuat di pasar. Perguruan tinggi level ini tidak saja memiliki finansial cukup mapan dibanding yang lain, tapi juga memiliki kualitas produk dan layanan yang baik. Mereka memiliki citra positif di masyarakat".

Dalam hal ini, UNIS Tangerang terus menjaga level ini secara terus menerus sehingga kualitas itu dapat dijaga dengan baik. Menjaga sesustu yang baik pada intinya adalah menjaga kualitas itu sendiri. Hal ini dilakukan agar UNIS Tangerang berada pada posisi leader yang secara terus menerus dapat dilakukan. Kalau banyak yang mengkomplain mengenai kualitas UNIS Tangerang yang dihasilkan, sesungguhnya itu sebuah trend penilaian masyarakat yang dewasa ini menghendaki UNIS agar tetap menjadi pangsa pasar perguruan tinggi yang tangguh.

Berbagai hal tentu harus dipertahankan bahkan terus diupayakan peningkatannya dari tahun ke tahun sehingga pangsa pasar UNIS Tangerang dapat terus dijaga. Hal ini tentu membuat suatu manajemen yang transparan sehingga dapat menerima kritikan secara internal dan eksternal.

\subsubsection{Tingkat Layanan Pada UNIS Tangerang}


Tingkat layanan ini merupakan hal yang sangat penting; yakni unitunit kerja yang ada di setiap fakultas, di UPK dan program pascasarjana memberikan layanan kepada mahasiswa berkaitan dengan PBM dan layanan kepada mahasiswa. Layanan ini hendaknya dapat diberikan ke mahasiswa dengan rasa puas. Tingkat kepuasan ini menjadi esensi dari makna sebuah pelayanan yang baik. Kalau ada mahasiswa yang belum merasakan adanya rasa puas berarti layanan itu masih kurang.

Pengamatan peneliti mengenai pelayanan in relatif berbeda bahwa kondisinya memang masih belum dirasakan oleh mahasiswa adanya rasa puas yang diterimanya, ada yang cepat, ada yang biasa-biasa aja, bahkan ada yang merasakan masih kurang baik. Rasa puas ini harus dapat diberikan kepada mahasiswa kalau UNIS Tangerang ingin maju.

Kamus Bisnis \& Bank (2005:832) menjelaskan: "Pangsa pasar adalah market segment yaitu: bagian dari keseluruhan permintaan suatu barang yang mencerminkan golongan konsumen menurut ciri khasnya, seperti tingkat pendapatan, umur, jenis kelamin, pendidikan, dan status sosial". Karena itu pangsa pasar juga bagian yang penting dari pelayanan. Pelayanan yang belum baik merupakan suatu tanggung-jawab dari setiap pimpinan, tentu harus dibicarakan dengan anggota organisasi lainnya, bahwa dewasa ini UNIS Tangerang belum bisa memberikan rasa puas dala pelayanan.

\subsubsection{Layanan Dari Sisi Apa}

Wijaya (2000:28) menjelaskan: “Faktor yang mempengaruhu mahasiswa mau kuliah salah satunya yang dipertimbangkan adalah jasa layanan yang disediakan". Oleh karena itu masih terdapat factor lain, seperti kemudahan pembayaran biaya kuliah, kualitas sumber daya mnusis, lokasi kampus, sarana prasaran kegiatan pendukung, kegiatan promosi, citra kampus, dan fasilitas penukung.

Layanan yang disediakan UNIS Tangerang dewasa ini cukup banyak, seperti dalam layanan akademik, PBM, surat menyurat, akreditasi program studi dan layanan lainnya. Layanan ini adalah layanan yang terstandarisasi, artinya layanan itu memiliki kekuatan hokum mengingat hal tersebut telah di buat dalam Surat Keputusan Rektor.

Mengembangkan pangsa pasar pada PTS bisa dilakukan dengan memperluas saluran distribusi, hal ini dilakukan untuk memperkenalkan dan mendekatkan UNIS Tangerang kepada konsumen, berdasarkan analisis konsumen tingkat pelayanan pada jaringan distribusi dan kemudahan mendapatkan akses akan menjadi faktor yang ikut 
menentukan keputusan konsumen untuk melakukan pembelian yakni memilih UNIS Tangerang sebagai tempat kuliah.

Untuk itu UNIS Tangerang tetap konsisten terhadap segala layanan yang diberikan dengan maksud agar mahasiswa bisa mengikuti proses studi dengan lancer sebagaimana waktu yang ditentukan. UNIS Tangerang memiliki layanan yang baik sebagaimana pendapat masyarakat dewasa ini.

\subsubsection{Layanan Di UNIS Jauh Lebih Baik}

UNIS Tangerang menjadi competitor yang baik, kualitas produk yang dilakukan UNIS Tangerang cukup dan layanan UNIS Tangerang kepada mahasiswa lebih baik. Memang masih ada sebagian kecil yang tidak sependapat; artinya memang diakui bahwa UNIS Tangerang belum bisa memberikan yang terbaik buat mahasiswa.

Layanan ini tentu berkaitan dengan pangsa pasar, seperti dikemukakan Pratama (2015:1) menjelaskan: "Pangsa pasar relatif merupakan suatu perbandingan volume penjualan yang dikuasai perusahaan tertentu dibandingkan dengan volume penjualan yang dikuasai oleh pesaing utama perusahaannya. Pangsa pasar ini biasanya berwujud sebuah angka mutlak dan bukan dalam bentuk persentase".

Semakin memberikan pemahaman yang mendalam bahwa pangsa pasar itu memiliki makna yang strategis karena ketika bicara pangsa pasar itu tergambarkan volume penjualan perusahaan dibandingkan dengan pesaing. Pesaing ini menjadi sesuatu yang menjadi perhitungan ketika membangun pangsa pasar; artinya pesaing itu mempertimbangkan faktorfaktor yang menjadi pertimbangan mahasiswa memilih tempat kuliah.

Mengenai citra produk ini juga berkaitan dengan penentuan harga (pricing), seperti dijelaskan oleh Hanafiah, (2015:39) mengemukakan: "Strategi penentuan harga (pricing) sangat signifikan dalam pemberian nilai kepada konsumen dan mempengaruhi citra produk, serta keputusan untuk membeli".

Dengan demikian hal yang menarik dari apa yang harus dilakukan adalah penentuan harga itu harus bisa memberikan kepada konsumen dan mempengaruhi citra produk dan keputusan untuk membeli; yakni memilih UNIS Tangerang tempat studi. Hal ini menjadi salah satu pemikiran bahwa layanan yang baik harus bisa diberikan kepada konsumen.

\subsection{Pangsa Pasar Dari Kekuatan Pesaing}

\subsubsection{Gambaran Pangsa Pasar di UNIS Tangerang}

Pangsa pasar adalah bagian atau luas pasar yang dikuasai oleh perguruan tinggi swasta (PTS) di dalam menjaring mahasiswa baru. Pangsa 
pasar ini tentu berkaitan dengan strategi pemasaran yang dapat dilakukan UNIS Tangerang sehingga bisa manrik mahasiswa baru. Pangsa pasar pada intinya merupakan indikator utama untuk mengukur seberapa baik yang dilakukan UNIS Tangerang dibanding dengan pesaing. Pangsa pasar yang ada harus bisa dikuasai termasuk bisa mengukur kekuatan pesaing yang dinyatakan dalam persentasi sehingga UNIS Tangerang pada setiap tahun mendapat mahasiswa baru yang banyak.

Pangsa pasar bagi UNIS Tangerang cukup potensial namun belum tentu calon mahasiswa itu bisa kuliah di UNIS Tangerang, hal in disebabkan karena disekitar UNIS Tangerang banyak terdapat competitor yang sama, yakni perguruan tinggi.

Mengenai pangsa pasar ini dijelaskan oleh Lapan (2017:1) tentang: "Pangsa pasar adalah salah satu indikator utama perusahaan yang digunakan untuk mengukur seberapa baik mereka lakukan dibandingkan pesaing. Pangsa pasar adalah persentase bisnis atau penjualan sebuah perusahaan yang memegang dari bisnis keseluruhan atau penjualan oleh semua pesaing gabungan di pasar tertentu".

Hal tersebut seperti dijelaskan oleh Hanafiah (2015:7) menyatakan: "Banyak organisasi menggunakan berbagai strategi untuk meningkatkan pangsa pasar, salah satunya melalui strategi kualitas. Dalam strategi pemasaran, konsumen merupakan tujuan jangka panjang perusahaan. Tujuan pemasaran adalah untuk memenuhi dan memuaskan kebutuhan serta keinginan konsumen".

Dengan demikian, gambaran pangsa pasar bagi UNIS Tangerang ini berkaitan dengan calon mahasiswa baru yang bisa memilih UNIS sebagai tempat studi dengan pertimbangan biaya kuliah dapat dibayar dengan baik.

\subsubsection{Keunggulan Dari Pangsa Pasar di UNIS Tangerang}

Strategi dan/atau taktik pemasaran merupakan hal yang utama untuk memenangkan pangsa pasar. Untuk memenangkan persaingan, UNIS Tangerang harus bisa menentukan pangsa pasar yang jelas sehingga dapat menganalisa peluang pasar dan pesaing sehingga dapat menerapkan promosi yang berbeda dengan pesaing. Inilah merupakan keunggulan yang harus dimiliki UNIS Tangeraang sehingga mampu melakukan persaingan dengan kompetitor.

Keunggulan yang dibangun PTS ini harus dapat dibedakan dengan produk lain dan memiliki citra tersendiri, dengan demikian produk akan mampu bersaing. Mengenai citra produk ini juga berkaitan dengan penentuan harga (pricing), seperti dijelaskan oleh Hanafiah, (2015:39) 
mengenai: "Strategi penentuan harga (pricing) sangat signifikan dalam pemberian nilai kepada konsumen dan mempengaruhi citra produk, serta keputusan untuk membeli".

Usaha yang dapat dilakukan UNIS Tangerang adalah mengembangkan keunggulan yang ada sehingga bisa bersaing dengan competitor. Keunggulan tersebut perlu dipertahankan dan dirawat sehingga pangsa pasar UNIS Tangerang tetap menjadi sesuatu yang positif. UNIS Tangerang sebagai perguruan tinggi swasta yang berada di Kota Tangerang harus sukses sebagai pemimpin pasar bukan berarti tidak diikuti oleh para pesaingnya; yakni PTS yang ada di Tangerang, di Provinsi Banten dan Jawa-Barat. Kesuksesan UNIS Tangerang yang terus mengembangkan produknya menghasilkan lulusan yang berkualitas merupakan bentuk merebut pangsa pasar.

\subsubsection{UNIS Sebagai Pesaing, Apakah Benar Kuat}

UNIS sebagai pesaing dari perguruan tinggi swasta tentu bisa saja, tapi apakah kuat. Sebagai pesaing tentu harus diakui banyak pesaing yang bermain pada perguruan tinggi swasta. Oleh karena itu, UNIS Tangerang perlu memperhatikan daya tarik bagi mahasiswanya, seperti bisa bermain pada tingkat harga yang diberikan kepada mahasiswa, kalau tidak berarti UNIS Tangerang tidak bisa memiliki kemampuan menguasai pangsa pasar.

UNIS Tangerang sebagai pesaing sudah kuat dari perguruan tinggi swasta yang ada di Tangerang. Kekuatan ini didukung dengan penggunaan sistem online dan dukungan publikasi dari dosen. Walaupun ada informan yang menjawab tidak kuat, hal itu bisa saja terjadi. Namun secara menyeluruh UNIS sebagai pesaing yang telah memiliki kekuatan dan dapat merebut pangsa pasar.

Hanafiah (2015:7) menyatakan: "Banyak organisasi menggunakan berbagai strategi untuk meningkatkan pangsa pasar, salah satunya melalui strategi kualitas. Dalam strategi pemasaran, konsumen merupakan tujuan jangka panjang perusahaan. Tujuan pemasaran adalah untuk memenuhi dan memuaskan kebutuhan serta keinginan konsumen".

Hasan (2008) menjelaskan: "Mempertahankan pasar dengan menciptakan entry barrier yang sulit atau bahkan tidak mungkin dilakukan pesaing". Untuk itu, dipertegas oleh Lapan (2017:1) menyatakan: "Pangsa pasar adalah salah satu indikator utama perusahaan gunakan untuk mengukur seberapa baik mereka lakukan dibandingkan pesaing".

Pangsa pasar ini menjadi sangat penting mengingat sebagai indikator kekuatan dalam menghadapi pesaing sehingga total bisnis yang berupa perosentase dapat direncanakan melalui strategi bersaing, Asmawi 
(2018:16) menjelaskan: “Dengan melakukan analisa kekuatan dan peluang digabung untuk memperoleh manfaat yang maksimal serta kelemahan dan ancaman digabung untuk meredam atau meminimalisasi dampak negatif".

Dengan demikian UNIS Tangerang sebagai pangsa pasar yang kuat sekaligus sebagai pesaing dari kompetitor baik PTS yang ada di Kota dan Kabupaten Tangerang.

\subsubsection{Seberapa Kuat UNIS Sebagai Pesaing}

Pangsa pasar adalah salah satu indikator utama perusahaan yang digunakan untuk mengukur seberapa baik mereka lakukan dibandingkan pesaing. Pangsa pasar ini menjadi sangat penting mengingat sebagai indikator kekuatan dalam menghadapi pesaing sehingga total bisnis yang berupa perosentase dapat direncanakan.

Mengenai pangsa pasar, dijelaskan oleh Lapan (2017:1) mengenai: "Pangsa pasar adalah salah satu indikator utama perusahaan yang digunakan untuk mengukur seberapa baik mereka lakukan dibandingkan pesaing. Ada dua cara dasar yang menyatakan angka pangsa pasar, meskipun perhitungan yang sebenarnya mungkin sulit untuk di dapatkan. Ada keuntungan dan kerugian untuk memiliki pasar yang besar pangsa relatif terhadap pesaing".

Mengkaji pangsa pasar pada intinya merupakan indikator utama untuk mengukur seberapa baik yang dilakukan UNIS Tangerang dibanding dengan pesaing. Pangsa pasar yang ada harus bisa dikuasai termasuk bisa mengukur kekuatan pesaing yang dinyatakan dalam persentasi, misal tahun 2018 berapa persen harus mendapatkan mahasiswa baru bila dibanding dengan tahun 2017, ini bisa dijadikan sebagai potensi pada pangsa pasar.

Dari kajian di atas dapat dipertegas bahwa UNIS Tangerang sebagai pesaing tentu dapat menguasai pangsa pasarnya sendiri, seperti yang bersumber dari mahasiswa dan lulusan ataupun dari masyarakat. Pangsa pasar itu secara kontinyu memberikan warna kepada UNIS Tangerang sehingga setiap tahun dapat terus meningkat jumlah mahasiswa barunya. 


\subsubsection{Kalau UNIS Sebagai Pesaing, Siapa Saja Orang Lain yang Anda Ketahui}

UNIS Tangerang sebagai perguruan tinggi swasta yang berada di Kota Tangerang harus sukses sebagai pemimpin pasar bukan berarti tidak diikuti oleh para pesaingnya; yakni PTS yang ada di Tangerang, di Provinsi Banten dan Jawa-Barat. Kesuksesan UNIS Tangerang yang terus mengembangkan produknya menghasilkan lulusan yang berkualitas merupakan bentuk merebut pangsa pasar.

Dengan demikian jelas UNIS sebagai pesaing, namun lawan pesaing dari UNIS Tangerang adalah PTS yang ada di kota dan kabupaten Tangerang. Pesaing UNIS Tangerang tersebut secara langsung atau tidak langsung mempengaruhi kompetensi UNIS terutama dalam hal berebut mahasiswa baru pada setiap tahun. Oleh karena itu UNIS Tangerang secara terus menerus menciptakan ruang gerak yang bisa dilakukan sehingga menjadikan pangsa pasar UNIS menjadi kuat.

Menurut Yavas dan Shemwell (19960); Hidayani dan Syafrizal (2008) dikutip Hariayanto (n.d:2), menjelaskan: "Posisi atau citra yang dibentuk oleh suatu perguruan tinggi memiliki peranan yang dominan dalam mempengaruhi sikap masyarakat terhadap perguruan tinggi tersebut. Sebagai contoh perguruan tinggi bisa memiliki citra sebagai perguruan tinggi yang murah, memiliki sistem penilaian yang baik, jadwal kuliah yang fleksibel, lokasi yang mudah dijangkau, atau memiliki sarana dan prasarana yang lengkap. Citra tersebut akan mempengaruhi calon mahasiswa dalam memilih universitas yang akan dipilih untuk pendidikan selanjutnya".

Mencermati apa yang dilakukan UNIS Tangerang berkaitan dengan potensi pangsa pasar perguruan tinggi swasta di Indnesia tentu sangat menarik untuk dilakukan revieu ulang mengingat hal ini berkaitan dengan citra dan penentuan harga, prime competitor, kualitas produk dan layanan. Dari hasil revieu yang dilakukan melalui wawancara dan pengamatan peneliti menunjukkan bahwa membangun citra dan penentuan harga bagi UNIS Tangerang telah dapat dilakukan dengan baik.

Sedang berkaitan dengan prime competitor, kualitas produk dan layanan masih berhadapan dengan kelemahan yang ditemukan di setiap program sudi. Menyangkut pangsa pasar dari kekuatan pesaing juga masih kurang baik walaupun UNIS Tangerang tidak harus menghindar dari pangsa pasar yang ada.

Dengan demikian dari kajian di atas selanjutnya dapat ditarik kesimpulan bahwa: 
Potensi pang sa pasar perguruan tinggi di Indonesia yang menyangkut: (1) citra dan penentuan harga; (2) prime competitor, kualitas produk dan layanan; dan (3) pangsa pasar dari kekutan pesaing cukup memiliki potensi yang baik.

Dengan berdasar pada kesimpulan tersebut, selanjutnya dapat ditarik kesmpulan (akhir), yakni:

Pangsa pasar Perguruan Tinggi Swasta (PTS) di Indonesia, yang dilakuakan studi pada Universitas Islam Syekh-Yusuf Tangerang adalah cukup potensil.

\section{E. DISKUSI}

Pada penelitian ini berkaitan dengan pangsa pasar pada Universitas Islam Syekh-Yusuf Tangerang menghasilkan cukup potensial yakni adanya animo masyarakat yang banyak masuk kuliah. Namun mengingat banyak terdapat kompetitor pada sektor yang sama yakni pendidikan tinggi, maka ketertarikan orang masuk ke perguruan tinggi swasta di Indonesia tentu dengan berbagai pertimbangan, seperti kualitas dan besaran biaya kuliah.

Dalam kaitan ini Universitas Islam Syekh-Yusuf Tangerang senantiasa perlu membangun keterpaduan anggota organisasi agar di dalam menghadapi tantangan dan persaingan bisa dihadapai dan mampu untuk bersaing. Dalam hal ini Universitas Islam Syekh-Yusuf Tangerang untuk terus membangun sinerji secara terkoordinasi sehingga menjadi kuat di dalam menghadapi persaingan mencari calon mahasiswa baru.

Diskusi ini diharapkan bisa menghasilkan kekuatan guna mencapai calon mahasiswa baru yang tent uterus bertambah dari tahun ketahun. Kekuatan dan pengalaman yang dimiliki tentu merupakan hal penting untuk terus dilakukan pembinaan kearah yang lebih baik lagi.

\section{F. KESIMPULAN}

Kesimpulan dari kajian potensi pangsa pasar perguruan tinggi swasta di Indonesia, yakni potensi pangsa pasar perguruan tinggi di Indonesia yang menyangkut: (1) citra dan penentuan harga; (2) prime competitor, kualitas produk dan layanan; dan (3) pangsa pasar dari kekuatan pesaing cukup memiliki potensi yang baik.

Agar potensi pasar perguruan tinggi swasta di Indonesia dapat tumbuh dengan baik diperlukan usaha pimpinan sehingga tetap tumbuh sesuai dengan apa yang diinginkan. 


\section{Declaration of Conflicting Interests}

The author(s) declared no potential conflicts of interest with respect to the research, authorship, and/or publication of this article.

\section{Funding}

The author(s) received no financial support for the research, authorship, and/or publication of this article.

\section{Referensi}

Asmawi, M. Rosul. (2017). 'The Importance of Leadership Style in the University: Research Study at Universitas Islam Syekh-Yusuf Tangerang, Indonesia'. Mediterranean Journal of Social Sciences. (8), 5 S1: 109-119. September 2017. Universitas Islam Syekh-Yusuf Tangerang, Indonesia.

Asmawi, M. Rosul. (2018). Manajemen Strategis. Fakultas Ilmu Sosial dan Ilmu Politik, Universitas Islam Syekh-Yusuf Tangerang.

Hanafiah, Vita. (2015). Strategi Pemasaran Lembaga Bimbingan Belajar Primagama Vila Nusa Indah Bogor. Skripsi, Program Studi Manajemen Pendidikan, Jurusan Kependidikan Islam, Fakultas Ilmu Tarbiyah dan Keguruan Universitas Islam Negeri Syarif Hidayatullah Jakarta.

Hariayanto, Criestiana. (n.d). 'Segmentasi dan Posisioning Perguruan Tinggi Swasta di Surabaya'. gracia0790@yahoo.com.

Hasyim, Rina Anindita. (2007). ‘Preferensi Calon Mahasiswa dalam Memilih Perguruan Tinggi Swasta'. Forum Ilmih Inonesia. (4), 1: 5459, JANUARI 2007.

Hendra, Sesario Tri Nur., \& Hartomo, Deny Dwi. (2017). 'Pengaruh Konsentrasi dan Pangsa Pasar terhadap Pengambilan Resiko Bank'. Jurnal Bisnis \& Manajemen. (17), 2, 2017: 35-50.

Handayani, A. (2017). 'Analisis Bauran Pemsaran terhadap Keputusan Mahasiswa Memilih Program Studi (Studi di Fakultas Ekonomi Universitas Bojonegoro)'. eprints.ums.ac.id.

Lapan, Hartono. (2017). Pengertian Market Share atau Pangsa Pasar. February 22, 2017. Https: 1.bp.blogspot.com

Miles, Matthew B., Huberman, A. Michael., \& Saldana. (2014). Qualitative Data Analysis: A Source Book of New Methods. Baverly Hills: SAGE Publications Inc.

Pohan, Kautsar Ridhalam (2010). Mempertahankan Market Leader pada Persaingan Pasar Pelumas Otomotif. Tesis, Fakultas Ekonomi, 
Program Studi Magister Manajemen, Kekhususan Pemasaran, Universitas Indonesia.

Rahadikha, Rizky., \& Sumarwan, Ujang. (2018). Analisis Strategi Manajemen Pemasaran Produk Rinso. Makalah.

Sopandi, Encep. (2011). 'Strategi Promosi Penerimaan Mahasiswa Baru Untuk PTS. (Tinjauan atas Kegiatan Promosi PTS di Jawa Barat Tahun 2010)'. Manajerial. (9), 18: 87-101. Januari 2011.

Susanti, Ari. (2017). 'Analisis Pengarauh Public Relation dan Pencitraan Terhadap Minat Kuliah di Pergurun Tinggi Swasta'. Jurnal Lentera Bisnis. 2017-plj.ac.id.

Wijaja, Tjandara. (2000). Analisis Faktor-Faktor yang Mempengaruhi Mahasiswa Memilih dan Kuliah di STIE Pariwisata Indonesia Semarang. Tesis, Program Studi Magaister Manajemen Program Pasca Sarjana Universitas Diponegoro Tahun 2000.

Kamus Bisnis \& Bank, dalam http://www.mediabpr.com/kamus-bisnisbank/pangsa_pasar.aspx), diakses tanggal 18 Maret 2018. 